\title{
Implementasi Tahap Pembiasaan Gerakan Literasi Sekolah
}

\author{
Nurmala Sari Burhan ${ }^{1}$, Nurchasanah ${ }^{2}$, Imam Agus Basuki ${ }^{2}$ \\ ${ }^{1}$ Pendidikan Dasar-Universitas Negeri Malang \\ ${ }^{2}$ Pendidikan Bahasa Indonesia-Universitas Negeri Malang
}

\section{INFO ARTIKEL}

\section{Riwayat Artikel:}

Diterima: 16-08-2019

Disetujui: 16-03-2020

\section{Kata kunci: \\ school literacy movements, habituation stage; gerakan literasi sekolah; tahap pembiasaan}

\author{
Alamat Korespondensi: \\ Nurmala Sari Burhan \\ Pendidikan Dasar \\ Universitas Negeri Malang \\ Jalan Semarang 5 Malang \\ E-mail: mala.nurmala291@ gmail.com
}

\begin{abstract}
ABSTRAK
Abstract: The purpose of this study is to describe the implementation of the school litersion movement in the Tanjung Redeb Elementary School. The schools selected in this study are SDN 002 Tanjung Redeb, SDN 004 Tanjung Redeb, and SDIT Ash-Shohwa because these elementary schools have implemented a school literacy movement policy. This research uses a qualitative research method of multi-site research. Data collected related to the implementation of the school literacy movement in the habituation stage. The data analysis technique starts with a single site data analysis followed by cross site data analysis. A single site analysis procedure is performed by presenting data, reducing data, and withdrawing conclusions. Cross-site analysis procedures are carried out by looking for temporary cross-site findings. Research results can be reviewed from the focus of the study. Each site engages in literacy habituation by providing literacy facilities and infrastructure in the form of library facilities, reading corners in the school environment and in the classrooms and reading areas. At the stage of habituation, the selection of appropriate reading books for literacy is carried out, carrying out literacy before learning with reading and writing activities, making the school environment rich in text through pictures and posters, and involving the public in the implementation of school literacy.

Abstrak: Tujuan penelitian ini untuk mendeskripsikan impementasi Gerakan Literasi Sekolah di Sekolah Dasar Tanjung Redeb. Sekolah yang dipilih dalam penelitian ini yaitu, SDN 002 Tanjung Redeb, SDN 004 Tanjung Redeb, dan SDIT Ash-Shohwa karena SD tersebut telah menerapkan kebijakan gerakan literasi sekolah. Penelitian ini menggunakan metode penelitian kualitatif jenis penelitian studi multisitus. Data yang dikumpulkan terkait implementasi gerakan literasi sekolah dalam tahap pembiasaan. Teknik analisis data dimulai dengan analisis data situs tunggal dilanjutkan dengan analisis data lintas situs. Prosedur analisis situs tunggal dilakukan dengan penyajian data, reduksi data, dan penarikkan kesimpulan. Prosedur analisis lintas situs dilakukan dengan mencari temuan sementara lintas situs. Hasil penelitian dapat ditinjau dari fokus penelitian. Setiap situs melakukan keggiatan pembiasaan literasi dengan dengan menyediakan sarana dan prasarana literasi berupa fasilitas perpustakaan, pojok baca di lingkungan sekolah dan di dalam kelas serta area baca. Pada tahap pembiasaan dilakukan kegiatan pemilihan buku bacaan yang tepat untuk literasi, melaksanakan literasi sebelum pembelajaran dengan kegiatan membaca dan menulis, membuat lingkungan sekolah kaya akan teks melalui gambar dan poster, dan melibatkan publik dalam pelaksanaan literasi sekolah.
\end{abstract}

Gerakan Literasi Sekolah adalah upaya menyeluruh yang melibatkan semua warga sekolah dan masyarakat, sebagai bagian dari ekosistem pendidikan. Gerakan Literasi Sekolah memperkuat gerakan penumbuhan budi pekerti sebagaimana dituangkan dalam Peraturan Menteri Pendidikan dan Kebudayaan Nomor 23 Tahun 2015. Berdasarkan permendikbud tersebut pada awal tahun 2016 diadakan program Gerakan Literasi Sekolah yang ditujukan untuk seluruh siswa dan warga sekolah lainnya. Gerakan Literasi Sekolahmelibatkan semua pemangku kepentingan di bidang pendidikan, mulai dari tingkat pusat, provinsi, kabupaten atau kota, hingga satuan pendidikan. Selain itu, pelibatan unsur eksternal dan unsur publik, yakni orangtua siswa, alumni, masyarakat, dunia usaha dan industri juga menjadi komponen penting dalam Gerakan Literasi Sekolah. Faizah, dkk (2016) mengemukakkan bahwa Gerakan Literasi Sekolah dikembangkan berdasarkan sembilan agenda prioritas (Nawacita) yang terkait dengan tugas dan fungsi Kemendikbud, khususnya Nawacita nomor 5, 6, 8, dan 9. Butir Nawacita yang dimaksudkan adalah (5) meningkatkan kualitas hidup manusia dan masyarakat Indonesia, (6) meningkatkan produktivitas rakyatdan daya saing di pasar internasional sehingga bangsa Indonesia dapat maju danbangkit bersama bangsa-bangsa Asia lainnya, (8) melakukan revolusi karakter bangsa, dan (9) memperteguh kebinekaan dan memperkuat restorasi sosial Indonesia 
Peraturan pemerintah menunjukkan bahwa Gerakan Literasi Sekolah sangat penting untuk diterapkan di sekolah dasar. Sejalan dengan yang diungkapkan oleh Muhammad (2016) bahwa Gerakan Literasi Sekolah merupakan usaha yang dilakukan untuk membiasakan, mengembangkan, dan membelajarkan literasi secara komprehensif dan berkesinambungan. Implementasi Gerakan Literasi Sekolah di sekolah dasar dapat dimulai dengan literasi dasar yaitu baca-tulis. Seperti yang telah diamanatkan dalam UU Sisdiknas pasal 4 tahun 2003 bahwa budaya membaca dilaksanakan untuk pendidikan. Berdasarkan sumber hukum negara Indonesia, maka disadari salah satu tugas pendidikan yaitu untuk meningkatkan kompetensi membaca dan mengembangkan budaya membaca siswa.

Menurut beberapa hasil penelitian dalam kutipan Antoro (2017) menyebutkan bahwa kegiatan membaca dapat menjaga kesehatan otak, meningkatkan kecerdasan logika dan linguistik sehingga siswa yang rajin membaca akan cenderung lebih baik dalam memahami berbagai persoalan, baik yang berkaitan dengan mata pelajaran di sekolah maupun dengan kehidupannya sehari-hari. Sejalan dengan yang dikumukakan oleh Mullis, dkk (2011) membaca dipandang sebagai komponen penting untuk kesuksesan sekolah dan siswa membutuhkan kemampuan membaca yang bagus untuk memahami dan mempelajari materi yang beragam di kelas. Gerakan Literasi Sekolah dilaksanakan di sekolah dasar mempunyai tujuan tersendiri, yaitu (1) menumbuhkembangkan budaya literasi membaca dan menulis siswa di sekolah, (2) meningkatkan kapasitas warga dan lingkungan sekolah agar sadar akan pentingnya budaya literasi, (3) menjadikan sekolah sebagai taman belajar yang menyenangkan dan ramah bagi siswa, dan (4) menghadirkan beragam buku bacaan dan mewadahi berbagai strategi membaca untuk mendukung keberlanjutan pembelajaran.

Program yang akan dilaksanakan atau akan diterapkan pasti mempunyai prinsip-prinsip tertentu, demikian pula dengan program Gerakan Literasi Sekolah yang dicanangkan pemerintah mempunyai prinsip-prinsip. Dalam hal ini, Suragangga (2017) berpendapat bahwa pelaksanaan program gerakan literasi sekolah mengacu pada prinsip (1) sesuai dengan tahapan perkembangan siswa, (2) dilaksanakan menggunakan berbagai ragam teks, (3) dilaksanakan secara terintegrasi dan holistik disemua area kurikulum, (4) dilakukan secara berkelanjutan, (5) melibatkan kecakapan berkomunikasi lisan, dan (6) mempertimbangkan keberagaman.

Mengacu pada prinsip tersebut, adapun tahapan pelaksanaan gerakan literasi sekolah dibagi ke dalam tiga tahapan, diantaranya tahap pembiasaan, pada tahapan ini, sekolah menyediakan berbagai buku dan bahan bacaan yang dapat menarik minat siswa dan melaksanakan kegiatan yang meningkatkan minat baca siswa. Peneliti kemudian melakukan studi pendahuluan berkaitan dengan Gerakan Literasi Sekolah di sekolah dasar pada beberapa sekolah di Kecamatan Tanjung Redeb, Kabupaten Berau, Provinsi Kalimantan Timur. Sekolah yang dipilih yaitu SDN 002 Tanjung Redeb, SDN 004 Tanjung Redeb, dan SDIT Ash-Shohwa. Sekolah tersebut dipilih menjadi sasaran penelitian karena merupakan SD yang letaknya di tengah kota dan menjadi sekolah rujukan dan unggulan di Kalimantan Timur.Berdasarkan survey awal yang dilakukan, ketiga SD tersebut telah menerapkan program Gerakan Literasi Sekolah. Hal ini dapat terlihat dari sarana dan prasarana yang menunjang keterlaksanaannya program Gerakan Literasi Sekolah tersebut. Sarana dan prasarana yang terlihat di lingkungan SDN 002 Tanjung Redeb dan SDN 004 Tanjung Redeb mempunyai kemiripan yaitu, terdapat pojok baca atau pojok literasi di pojok ruang kelas dengan berbagai jenis buku cerita yang digunakan untuk kegiatan membaca 15 menit sebelum belajar. Berbeda dengan SDIT Ash-Shohwa selain pojok baca atau pojok literasi yang dimiliki setiap kelas, juga terdapat beberapa pendopo atau teras baca yang terletak di depan beberapa kelas tepatnya di tepi halaman sekolah yang biasa digunakan siswa untuk membaca buku dan belajar.

Berdasarkan studi pendahuluan yang telah dilakukan, setiap sekolah pasti mempunyai strategi yang berbeda-beda dalam penerapan program Gerakan Literasi Sekolah. Oleh karena itu, dalam konteks penelitian ini peneliti ingin memotret secara mendalam mengenai implementasi program Gerakan Literasi Sekolah khususnya pada tahap pembiasaan di tiga situs, yaitu SDN 002, SDN 004, dan SDIT Ash-Shohwa Kecamatan Tanjung Redeb.

\section{METODE}

Desain penelitian yang digunakan dalam penelitian ini adalah metode kualiatif. Denzin and Lincoln (2000) yang mengatakan metode kualitatif berusaha mempelajari objek dalam keadaan yang sebenar-benarnya atau alamiah, kemudian berusaha untuk memahami dan menginterpretasikan fenomena yang terjadi dan maknanya yang melekat pada kehidupan manusia. Adapun tujuan dari penelitian kualitatif menurut Saldana (2011) mengemukakan tujuan penelitian kulitatif yang beragam, tergantung pada konteks proyek yang dilaksanakan. Berdasarkan definisi para ahli tersebut, dapat dipahami bahwa pendekatan kualitatif adalah cara pandang penelitian dalam menggambarkan kondisi kompleks yang alamiah berdasarkan konteks atau fokus penelitian. Penelitian ini berusaha untuk mengungkapkan fenomena di lapangan mengenai gerakan literasi sekolah.

Desain penelitian pada penelitian ini ingin menangkap fenomena dari tiga sekolah dasar, maka peneliti menggunakan jenis penelitian studi multisitus. Seperti yang dikemukan oleh Ulfatin (2015) penelitian studi multisitus merupakan penelitian yang menggunakan beberapa situs dan subjek penelitian sebagai kasus yang akan diungkap dimasing-masing situs. Rancangan studi multisitus adalah suatu rancangan penelitian kualitatif yang melibatkan beberapa situs, tempat, dan subjek penelitian. Subjek-subjek penelitian tersebut diasumsikan memiliki karakteristik yang sama. Sebagaimana dikemukakan oleh Bogdan and Biklen (2006), studi multisitus merupakan salah satu bentuk penelitian kualitatif yang memang dapat digunakan terutama untuk mengembangkan teori yang diangkat dari beberapa latar penelitian yang serupa, sehingga dapat dihasilkan teori yang dapat 
ditrasfer ke situasi yang lebih luas dan lebih umum cakupannya. Penelitian dengan menggunakan studi multisitus yang membutuhkan beberapa situs yang akan digunakan sebagai lokasi penelitian. Sekolah yang menjadi sasaran penelitian ini terdiri dari tiga sekolah dasar yaitu SDN 002 Tanjung Redeb sebagai situs I, SDN 004 Tanjung Redeb sebagai situs II, dan SDIT AshShohwa sebagai situs III. Ketiga situs ini berlokasi di Kecamatan Tanjung Redeb, Kabupaten Berau, Kalimantan Timur. Data yang dikumpulkan ditiap situs terkait implementasi gerakan literasi sekolah dalam tahap pembiasaan. Sumber data penelitian meliputi kepala sekolah, guru kelas/wali kelas, dan pengelola perpustakaan. Pengumpulan data melalui observasi, wawancara, dan dokumentasi.

Analisis data dalam penelitian multisitus terbagi menjadi dua tahapan. Pada tahapan pertama peneliti akan melakukan analisis data situs tunggal, tahap ini bertujuan untuk menemukan temuan-temuan sementara dari masing-masing situs. Pada tahapan kedua akan dilakukan analisis data lintas situs untuk menganalisis data dari ketiga situs hingga dapat menarik suatu kesimpulan. Analisis dan pengumpulan data secara berulang dilakukan agar dapat mengembangkan pola deskriptif pada keseluruhan situs. Ulfatin (2015) mengemukakan langkah-langkah dalam melaksanakan analisis lintas situs dengan metode induksi analitik modifikasi yaitu (1) membuat definisi kasar, (2) menyatukan data yang sesuai, (3) memodifikasi atau memberikan penjelasan terhadap kasus baru yang ditemukan karena tidak sesuai dengan definisi awal, (4) mendalami kasus yang tidak sesuai dengan definisi sebelumnya, dan (5) membuat definisi terkait fenomena tersebut dan menjelaskannya kembali hingga mendapatkan keterkaitan yang bersifat umum. Penggunakan metode analisis ini untuk isu kasus yang terdapat dalam fokus penelitian. Melalui tahapan analisis lintas situs diharapkan dapat menghasilkan keterkaitan yang bersifat universal tentang implementasi Gerakan Literasi Sekolah tahap pembiasaan.

Prosedur analisis situs tunggal dilakukan dengan pengumpulan data dan analisis data ketiga situs hingga menemukan temuan sementara pada masing-masing situs lalu dilanjutkan dengan memadukan ketiga temuan sementara tersebut menjadi temuan sementara antar situs. Kemudian dilakukan analisis data lintas situs. Prosedur analisis lintas situs akan dilakukan uji terhadap temuan-temuan di situs pertama dengan temuan situs kedua dan ketiga atau sebaliknya, sehingga menghasilkan temuan baru. Temuan-temuan baru inilah yang akan menjadi temuan akhir yang dibentuk menjadi proposisi-proposisi yang saling mendukung dari ketiga situs yang skan diusulkan menjadi teori subtantif tentang implementasi Gerakan Literasi Sekolah. Pengecekan keabsahan data melalui kriteria kepercayaan, keteralihan, ketergantungan, dan kepastian.

\section{HASIL}

Hasil dan pembahasan pada penelitian ini terbagi menjadi beberapa bagian yaitu, (1) temuan situs tunggal, (2) temuan lintas situs. Penelitian ini menggunakan tiga situs sebagai sumber data yaitu, SDN 002 Tanjung Redeb, SDN 004 Tanjung Redeb, dan SDIT Ash-Shohwa. Berikut pemaparan hasil dan pembahasan penelitian terkait implementasi Gerakan Literasi Sekolah pada tahap pembiasaan.

\section{Temuan Situs Tunggal}

Temuan situs tunggal akan memaparkan temuan penelitian dari setiap situs yaitu, (1) paparan data SDN 002 Tanjung Redeb, (2) paparan data SDN 004 Tanjung Redeb, dan (3) paparan data SDIT Ash-Shohwa.

Pertama, temuan penelitian SDN 002 Tanjung Redeb. Temuan data dari pembiasaan dalam implementasi gerakan literasi di SDN 002 Tanjung Redeb, diperoleh temuan penelitian sebagai berikut. (1) penataan sarana dan prasarana literasi terus dikembangkan yang menckup perpustakaan, pojok literasi sekolah dan area baca, (2) pemilihan bahan bacaan untuk literasi berupa buku fiksi dan non fiksi dengan Bahasa bilingual, atau memuat dua bahasa dalam satu buku cerita, (3) membaca sebelum pembelajaran dilakukan dengan membaca buku di setiap kelas sebelum pembelajaran dimulai, kegiatan membaca dilakukan juga di luar kelas dengan seluruh siswa pada hari jumat, (4) lingkungan kaya teks ditunjukkan dengan teks bergambar bermuatan motivasi dan slogan-slogan yang terdapat di tembok sekolah dan di setiap koridor sekolah dan karya siswa yang ditempel di mading sekolah, dan (5) melibatkan publik yang mencakup orangtua murid dan perpustakaan daerah dalam pelaksanaan kegiatan literasi sekolah.

Kedua, Temuan Penelitian SDN 004 Tanjung Redeb. Temuan data dari pembiasaan dalam implementasi gerakan literasi di SDN 004 sebagai berikut. (1) penataan sarana dan prasarana literasi mencerminkan pembiasaan literasi yang menckup perpustakaan, pojok literasi sekolah, dan area baca, (2) pemilihan bahan bacaan untuk literasi berupa buku fiksi dan non fiksi dan diarahkan kepada cerita yang mengandung penguatan karakter siswa, (3) membaca sebelum pembelajaran dilakukan setiap hari dengan membaca buku di masing-masing kelas sebelum pembelajaran dimulai, (4) lingkungan kaya teks ditunjukkan melalui lingkungan sekolah yang indah dihiasi dengan berbagai gambar, poster, teks yang tersebar di penjuru sekolah dari tembok, ruang UKS, kantin hingga di dalam kelas dengan berbagai informasi menarik, dan (5) melibatkan publik yang mencakup orang tua wali murid dan perpustakaan daerah dalam pengadaan buku dan pembinaan perpustakaan.

Ketiga, temuan penelitian SDIT Ash-Shohwa. Temuan data dari pembiasaan dalam implementasi gerakan literasi di SDIT Ash-Shohwa, diperoleh temuan penelitian sebagai berikut. (1) penataan sarana dan prasarana literasi mencerminkan pembiasaan literasi, terdapat perpustakaan dan area baca sekolah yang digunakan untuk kegiatan berliterasi, (2) pemilihan bahan bacaan untuk literasi berupa buku fiksi dan non fiksi dan mengarah pada buku dengan tema agama islam, mulai dari gambar-gambar hingga cerita yang tertuang didalam buku, (3) membaca sebelum pembelajaran diisi kegiatan majelis pagi, yaitu membacakan atau bercerita kisah-kisah maupun tokoh-tokoh islam dan kegiatan rabu literasi yang berbeda disetiap minggunya, 
meliputi mendongeng, menulis, membaca, dan wahana kreasi literasi, (4) lingkungan kaya teks ditunjukkan melalui lingkungan sekolah penuhi dengan berbagai teks dan poster-poster yang memberikan informasi dan penanaman karakter untuk warga sekolah dan teks berupa teks bilingual. Teks tersebut berada di area parkir, aula, dinding sekolah, area baca, UKS hingga toilet, hasil karya siswa turut menghiasi dinding-dinding setiap kelas, dan (5) melibatkan publik yang mencakup orangtua murid dalam pengadaan buku di pojok baca kelas, perpustakaan umum dengan mendatangkan perpustakaan keliling di lingkungan sekolah, serta sekolah juga sering mendatangkan berbagai komunitas-komunitas untuk mengisi rabu literasi dan membantu penerbitan majalah sekolah.

\section{Temuan Lintas Situs}

Temuan lintas situs merupakan temuan berdasarkan pemaparan dan temuan situs tunggal. Berikut ini temuan lintas situs dan menjadi temuan akhir penelitian.

Tabel 1. Temuan Lintas Situs Tahap Pembiasaan dalam Implementasi Gerakan Literasi Sekolah

\begin{tabular}{|c|c|c|c|c|}
\hline $\begin{array}{l}\text { Sub Fokus } \\
\text { Penelitian }\end{array}$ & $\begin{array}{c}\text { Temuan situs } 1 \\
\text { (SDN } 002 \text { Tanjung Redeb) }\end{array}$ & $\begin{array}{c}\text { Temuan situs } 2 \\
\text { (SDN } 004 \text { Tanjung Redeb) }\end{array}$ & $\begin{array}{c}\text { Temuan situs } 3 \\
\text { (SDIT Ash-Shohwa) }\end{array}$ & Temuan Lintas Situs \\
\hline $\begin{array}{c}\text { Sarana Dan } \\
\text { Prasarana Literasi }\end{array}$ & $\begin{array}{l}\text { Penataan sarana dan prasarana } \\
\text { literasi terus dikembangkan } \\
\text { yang menckup perpustakaan, } \\
\text { pojok literasi sekolah dan area } \\
\text { baca }\end{array}$ & $\begin{array}{l}\text { Penataan sarana dan } \\
\text { prasarana literasi } \\
\text { mencerminkan pembiasaan } \\
\text { literasi yang menckup } \\
\text { perpustakaan, pojok literasi } \\
\text { sekolah, dan area baca }\end{array}$ & $\begin{array}{l}\text { Penataan sarana dan } \\
\text { prasarana literasi } \\
\text { mencerminkan } \\
\text { pembiasaan literasi } \\
\text { yang perpustakaan dan } \\
\text { area baca sekolah }\end{array}$ & $\begin{array}{l}\text { Tersedia sarana dan prasarana } \\
\text { literasi yang berupa } \\
\text { perpustakaan, pojok literasi } \\
\text { sekolah, dan area baca }\end{array}$ \\
\hline $\begin{array}{l}\text { Pemilihan Bahan } \\
\text { Bacaan }\end{array}$ & $\begin{array}{l}\text { Pemilihan bahan bacaan } \\
\text { untuk literasi berupa buku } \\
\text { fiksi dan non fiksi dengan } \\
\text { Bahasa bilingual }\end{array}$ & $\begin{array}{l}\text { Pemilihan bahan bacaan } \\
\text { untuk literasi berupa buku } \\
\text { fiksi dan non fiksi dan } \\
\text { diarahkan kepada cerita } \\
\text { yang mengandung } \\
\text { penguatan karakter siswa }\end{array}$ & $\begin{array}{l}\text { Pemilihan bahan } \\
\text { bacaan untuk literasi } \\
\text { berupa buku fiksi dan } \\
\text { non fiksi dan mengarah } \\
\text { pada buku yang } \\
\text { bertemakan agama } \\
\text { islam dari gambar- } \\
\text { gambar hingga cerita } \\
\text { yang tertuang didalam } \\
\text { buku }\end{array}$ & $\begin{array}{l}\text { Memilih buku bacaan untuk } \\
\text { literasi berupa buku fiksi dan } \\
\text { non fiksi }\end{array}$ \\
\hline $\begin{array}{l}\text { Membaca } 15 \\
\text { Menit Sebelum } \\
\text { Pembelajaran }\end{array}$ & $\begin{array}{l}\text { Membaca sebelum } \\
\text { pembelajaran dilakukan } \\
\text { dengan membaca buku } \\
\text { dimasing-masing kelas } \\
\text { sebelum pembelajaran dan } \\
\text { dilakukan juga diluar kelas } \\
\text { dengan seluruh siswa pada } \\
\text { hari jumat }\end{array}$ & $\begin{array}{l}\text { Membaca sebelum } \\
\text { pembelajaran dilakukan } \\
\text { setiap hari dengan membaca } \\
\text { buku dimasing-masing } \\
\text { kelas sebelum pembelajaran } \\
\text { dimulai }\end{array}$ & $\begin{array}{l}\text { Membaca sebelum } \\
\text { pembelajaran diisi } \\
\text { kegiatan majelis pagi, } \\
\text { yaitu membacakan atau } \\
\text { bercerita kisah-kisah } \\
\text { islam dan kegiatan rabu } \\
\text { literasi yang berbeda } \\
\text { disetiap minggunya, } \\
\text { meliputi mendongeng, } \\
\text { menulis, membaca, dan } \\
\text { waha kreasi literasi }\end{array}$ & $\begin{array}{l}\text { Literasi sebelum } \\
\text { pembelajarandilakukan dengan } \\
\text { membaca dan menulis }\end{array}$ \\
\hline $\begin{array}{l}\text { Lingkungan Kaya } \\
\text { Teks }\end{array}$ & $\begin{array}{l}\text { Lingkungan kaya teks } \\
\text { ditunjukkan dengan teks } \\
\text { bergambar bermuatan } \\
\text { motivasi dan selogan-selogan } \\
\text { yang terdapat di tembok } \\
\text { sekolah dan disetiap koridor } \\
\text { sekolah dan karya siswa yang } \\
\text { ditempel di mading sekolah }\end{array}$ & $\begin{array}{l}\text { Lingkungan kaya teks } \\
\text { ditunjukkan melalui } \\
\text { lingkungan sekolah yang } \\
\text { indah dihiasi dengan } \\
\text { berbagai gambar, poster, } \\
\text { teks yang tersebar di } \\
\text { penjuru sekolah dari } \\
\text { tembok, ruang UKS, kantin } \\
\text { hingga di dalam kelas } \\
\text { dengan berbagai informasi } \\
\text { menarik }\end{array}$ & $\begin{array}{l}\text { Lingkungan kaya teks } \\
\text { ditunjukkan melalui } \\
\text { lingkungan sekolah } \\
\text { penuhi dengan berbagai } \\
\text { teks dan poster-poster } \\
\text { yang memberikan } \\
\text { informasi dan } \\
\text { penanaman karakter } \\
\text { untuk warga sekolah } \\
\text { dan teks berupa teks } \\
\text { bilingual yang terletak } \\
\text { di area parkir, aula, } \\
\text { dinding sekolah, area } \\
\text { baca, UKS, hingga } \\
\text { toilet, hasil karya siswa } \\
\text { turut menghiasi } \\
\text { dinding-dinding setiap } \\
\text { kelas }\end{array}$ & $\begin{array}{l}\text { Membuat lingkungan sekolah } \\
\text { kaya akan teks terletak di area } \\
\text { parkir, aula, dinding sekolah, } \\
\text { area baca, UKS, hingga toilet, } \\
\text { hasil karya siswa turut } \\
\text { menghiasi dinding-dinding } \\
\text { setiap kelas }\end{array}$ \\
\hline
\end{tabular}


Tabel 1. Temuan Lintas Situs Tahap Pembiasaan dalam Implementasi Gerakan Literasi Sekolah (Lanjutan)

\begin{tabular}{|c|c|c|c|c|}
\hline $\begin{array}{l}\text { Sub Fokus } \\
\text { Penelitian }\end{array}$ & $\begin{array}{c}\text { Temuan situs } 1 \\
\text { (SDN 002 Tanjung Redeb) }\end{array}$ & $\begin{array}{c}\text { Temuan situs } 2 \\
\text { (SDN 004 Tanjung Redeb) }\end{array}$ & $\begin{array}{c}\text { Temuan situs } 3 \\
\text { (SDIT Ash-Shohwa) }\end{array}$ & Temuan Lintas Situs \\
\hline Pelibatan Publik & $\begin{array}{l}\text { Melibatkan publik yang } \\
\text { mencakup orang tua wali } \\
\text { murid dan perpustakaan } \\
\text { daerah }\end{array}$ & $\begin{array}{l}\text { Melibatkan publik yang } \\
\text { mencakup orang tua wali } \\
\text { murid dan perpustakaan } \\
\text { daerah dalam pengadaan } \\
\text { buku dan pembinaan } \\
\text { perpustakaan }\end{array}$ & $\begin{array}{l}\text { Melibatkan publik yang } \\
\text { mencakup orang tua } \\
\text { wali murid dalam } \\
\text { pengadaan buku di } \\
\text { pojok baca kelas, } \\
\text { perpustakaan umum } \\
\text { dengan mendatangkan } \\
\text { perpustakaan keliling } \\
\text { di lingkungan sekolah, } \\
\text { serta sekolah juga } \\
\text { sering mendatangkan } \\
\text { berbagai komunitas- } \\
\text { komunitas untuk } \\
\text { mengisi rabu literasi } \\
\text { dan membantu } \\
\text { penerbitan majalah } \\
\text { sekolah }\end{array}$ & $\begin{array}{l}\text { Melibatkan publik dalam } \\
\text { implementasi literasi mulai } \\
\text { dari orang tua siswa, } \\
\text { perpustakaan daerah atau } \\
\text { perpustakaan umum hingga } \\
\text { berbagai komunitas yang } \\
\text { menunjang implementasi } \\
\text { Gerakan Literasi Sekolah }\end{array}$ \\
\hline
\end{tabular}

Berdasarkan temuan lintas situs di atas, maka dapat diformulasikan pada gambar sebagai temuan akhir. PenelitianTahap Pembiasaan dalam Implementasi Gerakan Litersi Sekolah di SDTanjung Redeb.

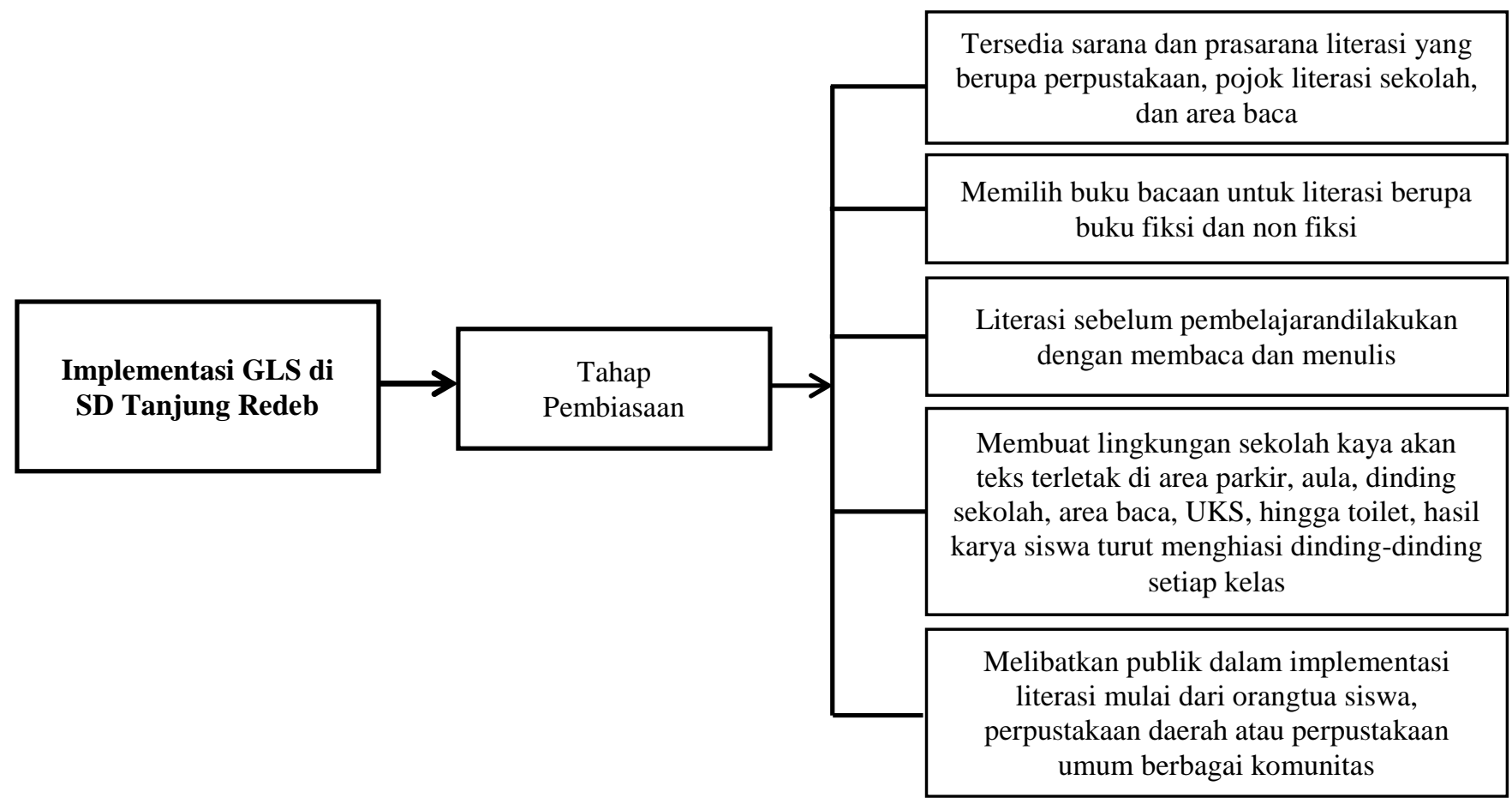

\section{Gambar 1. Temuan Akhir Penelitian Tahap Pembiasaan dalam Implementasi Gerakan Litersi Sekolah di SD Tanjung Redeb}

\section{PEMBAHASAN}

Implementasi gerakan literassi sekolah di SD dimulai dari tahap pembiasaan untuk menciptakan ekosistem warga sekolah yang literat. Seperti yang diungkapkan oleh Suyono, dkk (2017) tujuan Gerakan Literasi Sekolah untuk menciptakan warga seolah yang literat dalam artian mampu memahami serta mengaplikasikan ragam teks dalam kehidupan bermasyarakat. Implementasi tahap pembiasaan Gerakan Literasi Sekolah di SD Tanjung Redeb berdasarkan temuan penelitian dilaksanakan dengan lima kegiatan yang meliputi penyadiaan sarana dan prasarana literasi yang berupa perpustakaan, pojok literasi sekolah, dan area baca, menciptakan lingkungan sekolah kaya akan teks di area parkir, aula, dinding sekolah, area baca, UKS hingga 
toilet, hasil karya siswa turut menghiasi dinding-dinding setiap kelas, memilih buku bacaan untuk literasi berupa buku fiksi dan non fiksi, literasi sebelum pembelajaran dilakukan dengan membaca dan menulis, dan melibatkan publik dalam implementasi literasi mulai dari orang tua siswa, perpustakaan daerah atau perpustakaan umum berbagai komunitas.

Pembiasaan dilaksanakan melalui kegiatan penyadiaan sarana dan prasarana yang menunjang kegiatan literasi yang berupa buku cerita yang tersedia di perpustakaan dan juga pojok baca setiap kelas, serta menyediakan area baca di lingkungan sekolah. Pelaksanaan tersebut dilakukan oleh sekolah di Tanjung Redeb relevan dengan pernyataan (Kompri, 2014, Ratnawati, 2017) yang mengatakan bahwa sarana literasi mencakup perpustakaan sekolah, sudut baca kelas, dan area baca yang merupakan sarana dan prasarana pendukung serta memaksimalkan proses pembelajaran dan literasi. Sarana dan prasarana perpustakaan merupakan tempat koordinasi sudut baca dan area baca yang telah disediakan sekolah berguna untuk pembiasaan literasi untuk warga sekolah. Sudut baca yang berada di setiap kelas sangat berperan penting dalam kegiatan pembiasaan literasi, karena siswa tidak perlu jauh-jauh ke perpustakaan untuk membaca buku cerita dan siswa dapat membaca kapan saja dengan mudah karena pojok baca tersebut. Pengadaan pojok baca setiap dalam tahap pembiasaan Gerakan Literasi Sekolah relevan dengan pernyataan Hastuti dan Lestari (2018) penataan sarana dan prasarana literasi tidak hanya perpustakaan, pengadaan sudut baca atau pojok baca disetiap kelas merupakan cara jitu dalam meningkatkan literasi di sekolah sehingga siswa tidak perlu jauh ke perpustakaan.

Temuan penelitian tidak hanya menunjukkan pembiasaan yang dilakukan pada penyediaan sarana dan prasarana perpustakaan dan pojok baca, lingkungan sekolah juga mencerminkan lingkungan literat dengan menciptakan lingkungan sekolah yang kaya akan teks di setiap sudut sekolah dimulai dari area parkir, aula, dinding sekolah, area baca, UKS hingga toilet, teks berupa teks bergambar, poster-poster yang memuat berbagai informasi, dan hasil karya siswa turut menghiasi dinding-dinding setiap kelas. Penciptaan lingkungan kaya teks ini relevan dengan pernyataan Kompri (2014) sarana selanjutnya yaitu area baca yang mendukung implementasi Gerakan Literasi Sekolah ini, meliputi lingkungan sekolah seperti halaman, kebun, UKS, ruang guru, koridor, ruang tunggu orangtua dll. Menciptakan lingkungan literasi merupakan hal penting dalam penerapan literasi khususnya pada pembiasaan dengan mengampanyekan gerakan literasi melalui poster atau tulisan- tulisan yang bersifat positif diberbagai sudut sekolah (Hastuti dan Lestari 2018).

Lingkungan kaya teks merupakan aspek penting dalam pembiasaan literasi untuk warga sekolah karena merupakan tempat siswa dan guru beraktivitas dan memberi pengaruh besar untuk menciptakan budaya literat. Hal ini selaras dengan Faizah, dkk (2016) dalam menciptakan budaya literasi diperlukan strategi penciptaan fisik yang ramah literasi. Lingkungan fisik menjadi aspek penting untuk dibangun karena lingkungan fisik merupakan yang pertama dilihat oleh siswa. Untuk dapat menumbuhkan budaya literasi, sekolah harus menciptakan lingkungan fisik yang ramah dan kondusif. Menurut Antasari (2015) menciptakan lingkungan sekolah kaya teks bertujuan agar siswa dapat terbiasa untuk membaca dan mengkaji apa yang ada disekitarnya, teks-teks yang tersebar di limgkungan sekolah berisi motivasi, berita, gambar, dan lain-lain. Oleh karena itu, dengan lingkungan sekolah kaya akan teks maka dapat menciptakan dan membiasakan siswa dalam berliterat.

Pembiasaan literasi pada tiga situs berdasarkan temuan penelitian menemukan pemilihan buku yang digunakan untuk literasi merupakan buku cerita fiksi dan non fiksi yang dapat berupa buku yang informasional, buku cerita pendek, novel, dongeng, kisah para tokoh yang memuat penanaman karakter dan bernilai moral. Hal tersebut relevan dengan yang diungkapkan oleh Faizah dkk (2016) jenis buku yang digunakan mengandung informasi sederhana hingga kompleks, dapat mengembangkan daya imajinatif siswa, condong ke arah fantasi seperti dongeng, cerita binatang (fabel) yang sesuai dengan tingkat perkembangan siswa dan mengandung nilai moral dan pesan yang baik. Suragangga (2017) mengungkapkan salah satu prinsip pelaksanaan literasi yaitu menggunakan beragam jenis teks dan sesuai dengan tingkat perkembangan siswa. Relevan dengan pernyataan Batubara dan Ariani (2018) buku yang digunakan dalam kegiatan literasi adalah buku cerita yang disesuaikan dengan karakteristik siswa dan keinginan siswa. Oleh karena itu, pemilihan buku bacaan yang tepat untuk siswa sangat berpengaruh pada tahap pembiasaan literasi di sekolah. Siswa harus membaca buku yang beraneka ragam dan tentunya sesuai dengan perkembangan siswa itu sendiri.

Selanjutnya temuan berdasarkan penelitian di ketiga SD tersebut melakukan literasi sebelum pembelajaran dilakukan dengan kegiatan membaca dan menulis yang merupakan literasi dasar untuk membiasakan siswa terhadap kegiatan literasi. Hal tersebut relevan dengan pernyataan Tryanasari, Aprilia, \& Cahya (2017) literasi secara sederhana merupakan sebuah kemampuan dalam membaca dan menulis. Pelaksanaan kegiatan literasi sebelum pembelajaran berkisar antara 10 - 15 menit sebelum kegiatan pembelajaran dimulai, pelaksanaan kegiatan tersebut dilakukan dan dikelola oleh guru dan siswa (Batubara dan Ariani, 2018). Pelaksanaan kegiatan membaca dan menulis dalam literasi sebelumbelajaran tersebut telah memenuhi amanat dari implementasi Gerakan Litarasi Sekolah. Seperti yang tercantum pada Faizah, dkk (2016) tujuan awal literasi yaitu memicu agar siswa mau membaca dan menumbuhkan kebiasaan membaca. Berdasarkan pemaparan temuan sekolah telah melaksanakan kegiatan membaca dan menulis dapat memberikan pengalaman literasi dasar bagi siswa.

Pembiasaan lainnya berdasarkan temuan penelitian ditiga SD juga melibatkan publik dalam implementasi Gerakan Literasi Sekolah. Masing-masing sekolah melakukan kerjasama dengan orang tua siswa, perpustakaan daerah atau perpustakaan umum berbagai komunitas dalam hal pengadaan buku, pelatihan ataupun membagikan ilmu dengan siswa maupun guru. Hal tersebut selaras dengan Faizah, dkk (2016) dalam mengembangkan sarana dan prasarana pendukung literasi diperlukan pelibatan publik dapat datang dari dari komite sekolah, orangtua, alumni, perpustakaan daerah, dan dunia bisnis maupun insdustri. Menururt Wandasari (2017) pelibatan publik merupakan usaha yang bersifat partisipatif dengan melibatkan warga sekolah, akademisi, penerbit, media massa, tokoh masyarakat dll. Selain itu, menurut Musafiyono \& Setyowati (2014) peran 
orang harus memahami pentingnya literasi untuk anak terutama anak usia dasar dengan melakukan dukungan atau terlibat dalam penyediaan fasilitas yang mendukung kegiatan literasi baik dirumah maupun di sekolah. Oleh karena itu, bila ketiga situs melibatkan publik maka terjadi kemajuan dalam implementasi Gerakan Literasi Sekolah.

\section{SIMPULAN}

Berdasarkan paparan data, temuan penelitian, dan pembahasan dari tiga situs penelitian, selanjutnya dirumuskan simpulan penelitian sebagai berikut. Ketiga sekolah di Tanjung Redeb melakukan berbagai upaya dan terus mengembangkan tahap pembiasaan dalam implementasi Gerakan Literasi Sekolah. Tahap pembiasaan merupakan titik awal untuk menumbuhkan minat literasi sekolah dengan berupaya: (1) menyediakan sarana dan prasarana literasi yang berupa perpustakaan, pojok literasi sekolah, dan area baca, (2) melakukan pemilihan buku bacaan untuk literasi berupa buku fiksi dan non fiksi, (3) melakukan literasi dasar yang dilakukan sebelum pembelajaran dengan kegiatan membaca dan menulis, (4) menciptakan lingkungan sekolah kaya akan teks di area parkir, aula, dinding sekolah, area baca, UKS, hingga toilet, hasil karya siswa turut menghiasi dinding-dinding setiap kelas, dan (5) melibatkan publik dalam implementasi literasi mulai dari orangtua siswa, perpustakaan daerah atau perpustakaan umum berbagai komunitas. Berdasarkan uapaya tersebut maka dapat disimpulkan bahwa pada tahap pembiasaan masing-masing SD yang diteliti telah malakukan atau menjalankan setiap tahapan-tahapan dalam pembiasaan Gerakan Literasi Sekolah. Namun, konsep penerapannya berbeda-beda di setiap sekolah, hal tersebut karena setiap SD mempunyai wewenang untuk merancang penerapan Gerakan Literasi Sekolah semenarik mungkin dalam membiasakan literasi di sekolah yang disesuaikan dengan latar belakang masing-masing sekolah.

\section{DAFTAR RUJUKAN}

Antasari, I. W. (2015). Implementasi Gerakan Literasi Sekolah Tahap Pembiasaan di MI Muhammadiyah Gandatapa Sumbang Banyumas. LIBRIA, 9(40), 13-26.

Antoro, B. (2017). Gerakan Literasi Sekolah. Dari Pucuk Hingga Akar.

Batubara, H. H., \& Ariani, D. N. (2018). Implementasi Program Gerakan Literasi Sekolah di Sekolah Dasar Negeri Gugus Sungai Miai Banjarmasin. Jurnal Pendidikan Sekolah Dasar, 4(1), 15-29.

Denzin, N. K., \& Y. Lincoln. (2000). Handbook of Qualitative Research. Thousand Oaks.

Faizah, D.U., Sufyadi, S., Anggraini, L., Waluyo, Dewayanti, S., Muldian, W., Roosaria, D. R. (2016). Panduan Gerakan Literasi Sekolah Di Sekolah Dasar. Jakarta: Direktorat Pembinaan Sekolah Dasar Direktorat Jenderal Pendidikan Dasar dan Menengah Kementerian Pendidikan dan Kebudayaan.

Hastuti, S., \& Lestari, N. A. (2018). Gerakan Literasi Sekolah: Implementasi Tahap Pembiasaan dan Pengembangan Literasi di SD Sukorejo Kediri. Jurnal Basataka, 1(2), 29-34.

Kemendikbud. (2018). Gerakan Literasi Sekolah. Jakarta: Direktorat Jenderal Pendidikan Dasar dan Menengah Kementerian Pendidikan dan Kebudayaan.

Kompri. (2014). Manajemen Pendidikan 2. Bandung: CV. Alfabeta.

Mullis, Ina V. S., Michael O. Martin, Pierre Foy, and Kathleen T. Drucker. (2011). PIRLS 2011 International Results in Reading. United States: TIMSS \& PIRLS International Study Center.

Musafiyono, W., \& Setyowati, N. (2014). Peran Orangtua Dalam Menumbuhkan Nasionalisme pada Anak Usia Sekolah Dasar. Kajian Moral dan Kewarganegaraan, 3(2), 1076-1094.

Ratnawati, L. A. (2017). Implementasi Gerakan Literasi Sekolah di SD Negeri Bhayangkara Yogyakarta. Skripsi tidak diterbitkan. Universitas Negeri Yogyakarta, Yogyakarta.

Saldaña, J. (2011). Fundamentals of Qualitative Research. Oxford University Press.

Suragangga, I. M. N. (2017). Mendidik Lewat Literasi Untuk Pendidikan Berkualitas. Jurnal Penjaminan Mutu 3(2), $154-63$.

Suyono., Harsiati, T., \& Wulandari, I. S. (2017). Implementasi Gerakan Literasi Sekolah Pada Pembelajaran Tematik di Sekolah Dasar. Sekolah Dasar: Kajian Teori dan Praktik Pendidikan, 26(2), 116-123.

Tryanasari, D., Aprilia, S., \& Cahya W. A. (2017). Pembelajaran Literasi di SDN Rejosari 1 Kecamatan Kawedanan Kabupaten Magetan. Premiere Educandum: Jurnal Pendidikan Dasar dan Pembelajaran, 7(02), 173-179.

Ulfatin, N. (2015). Metode Penelitian Kualitatif: Teori dan Aplikasinya. Malang: Media Nusantara Creative.

Wandasari, Y. (2017). Implementasi Gerakan Literasi Sekolah sebagai Pembentuk Pendidikan Berkarakter. JMKSP (Jurnal Manajemen, Kepemimpinan, dan Supervisi Pendidikan), 2(2), 325-343. 